\title{
Several Issues of Realisation of the Assumption of Innocence Principle in the Criminal Proceeding
}

\author{
Alimkulov Erbol Temirkhanovich \\ PhD (Law), Associate Professor of the Department of Criminal Law, Criminal Procedure and Criminalistics \\ Al-Farabi Kazakh National University, Kazakhstan, Almaty; Corresponding author's mail: alerbol@mail.ru
}

Bayandina Mainur Okanovna

Senior Lecturer of the Department of Criminal Law, Criminal Procedure and Criminalistics Al-Farabi Kazakh National University Kazakhstan, Almaty

\section{Bersugurova Lyaziza Shaltaevna}

Full Doctor of Law, Professor of the Department of Criminal Law, Criminal Procedure and Criminalistics Al-Farabi Kazakh National University Kazakhstan, Almaty

\section{Zhanibekov Akynkozha Kalenovich}

PhD, Associate Professor of the Department of Criminal Law, Criminal Procedure and Criminalistics Al-Farabi Kazakh National University Kazakhstan, Almaty

\section{Mukhamadieva Gul'zhan Nusupzhanovna}

Associate Professor of the Department of Criminal Law, Criminal Procedure and Criminalistics Al-Farabi Kazakh National University Kazakhstan, Almaty

Doi:10.5901/mjss.2015.v6n6p256

Abstract

The article deals with the legal nature of the assumption of innocence as a fundamental and principle source of Kazakhstan criminal proceeding. The author actualizes a need for further development of legislation defining legal framework of the assumption of innocence in criminal proceeding. Author has addressed matters related to the influence of the assumption of innocence upon different aspects of criminal averment under adversary criminal proceeding.

Keywords: assumption of innocence principle, criminal proceeding, character of evidence, averment, court investigation.

\section{Introduction}

Democratic development of criminal proceeding providing observance of rights and lawful interests of citizens under criminal proceedings is based upon principles enshrined in the Constitution and the Criminal Procedure Code. Analysis of the principles of criminal procedure shows that the majority of them (justness, inviolability of person, respect of the person's honour and dignity, equality of rights of the person and of the citizen before the law and the court etc.) are guaranteed by the constitutional law of the country. Such principles are generally legal, which represents the nature and essence of constitutional democracy. These principles profess the person, his/her rights and freedoms to be the supreme value and achievement of the state. They should be effective under the integral system of criminal proceeding and at all of its stages. Being the guidelines and functional components of criminal proceeding organisation, all the principles are subordinate to the common purpose - the protection of person's rights and freedoms. Comprehensive implementation of each principle depends upon subsequent implementation of other equally important provisions. However, each principle plays its own individual part in an integral system. One of such principles is the principle of assumption of innocence. At present the problems of assumption of innocence has explicit perspectives for legal solution, which is primarily associated with democratic revisions of the whole state - legal system of the republic. A person with a complex of his/her natural, 
inalienable and acquired rights and freedoms becomes the fundamental principle in our state - and not only for regulation of legal acts, but also in real-life conditions. We think that this is promoted by political and legal direction of development of democratic relations in the republic. Difficulty of a chosen direction is each time emphasized by dogmatics of transition period, creating conditions for search, for difficult decisions and ubiquitous mistakes. This factor is also represented by the results of numerous rounds of legal reforms started in the beginning of 1990s. However, today we can insist that it is a stagewise reforming that promotes achievement of targeted rates, as law-maker uses not only rules of law-making, but also our local experience of law enforcement.

\section{The Presumption of Innocence as a Cornerstone of the Legal System}

Principle of presumption of innocence (Art.19 of CrPC RK) [Criminal Procedure Code of the Republic of Kazakhstan, 2014] is consistent with provision of Art. 77 of the Constitution of RK, which raises it to the level of constitutional principle of criminal justice [Constitution of the Republic of Kazakhstan, 1996]. Principle of presumption of innocence is established by international legal acts. Thus, The Universal Declaration of Human Rights, Chapter 1 Art.11 states: " Everyone charged with a penal offence has the right to be presumed innocent until proved guilty according to law in a public trial at which he has had all the guarantees necessary for his defence" [Universal Declaration of Human Rights, 1948]. The International Covenant on Civil and Political Rights states: "Everyone charged with a criminal offence shall have the right to be presumed innocent until proved guilty according to law" (p.2 Art.14) [International Covenant on Civil and Political Rights, 1966].

This basic principle of criminal procedure is fixed by law and is in force until the imposition of sentence. Violation of this principle leads to the violation of principles of justness and inviolability of person, as there is pronouncement of a priori illegal sentence, administration of a priori illegal arrest or detention, compulsion of evidence. There still are cases of different violations in work of agencies, conducting criminal proceeding - the most serious of them are prosecution and conviction of innocent persons. For more profound guarantees of inviolability of person, current legislation contains provisions regulating the procedure of detection and rectification of judicial and inquisitional errors. These provisions guarantee in particular the right of citizens for rebuttal and rehabilitation. Legal act attesting innocence is an absolutory sentence or ruling for termination of criminal case on one of the grounds provided for by Art.37 CrPC RK [Criminal Procedure Code of the Republic of Kazakhstan, 2014]. Such act states complete innocence of an indicted person, reestablishes his/her status as a full citizen, i.e. states rehabilitation.

According to p.2, 3, 4 of Art.19, presumption of innocence is the source for rules of averment. According to p.2 Art. 19 of CrPC, "nobody shall be obliged to prove his innocence" and "unresolvable doubts with regard to the culpability of an accused person shall be interpreted for his benefit. Any doubts which arise when applying criminal and criminal procedure laws must be settled for the benefit of the accused" of p.3 Art.19 [Criminal Procedure Code of the Republic of Kazakhstan, 2014].

These critical principles of averment represent universal human legal values. They are stated in Art.14 p. 2 of the International Covenant on Civil and Political Rights [International Covenant on Civil and Political Rights, 1966] and are source for the rules to be applied upon averment. This means that defendant shall not be liable legally or factually (as to adverse effects) to present evidence of his innocence. Court judgement of guilt cannot be based on the failure of accused to deny prosecution or to provide favourable evidence, or even on refuse to give a statement. Non-provision of favourable evidence by the accused person as well as his refuse to give a statement cannot be regarded as a proof of guilt. Accused (suspect) person's refuse to give a statement or his mute do not have any legal meaning and cannot be used as proof of his guilt. According to the Articles $68-69$ of CrPC RK, the accused and suspect shall have a right and no obligation to give explanation or statement concerning suspicions against him, as well as present evidence. In addition, accused (suspect) has a right to completely refuse to give any explanations or statements. Accused shall not be obliged to prove his statement with evidences or to give evidences or point them in order to justify his actions. All the explanations of the accused and evidences pointed by him shall be verified by the investigator, the court.

There is a commanding view among scientists-processualists that evaluation of evidences involves establishing of following properties: relevance, admissibility, credibility and sufficiency for validation of conclusions. Relevance of evidence is an inner property of evidence characterising factual data, capable of establishing the facts as meaningful for just determination of a criminal cause [Criminal Procedure Legislation of RK, 2004].

Vyshinsky A.Ya. suggested to solve the question on admissibility of evidence to the court and investigation with no restrictions of "formal limits" of the law. Thus, the "concept" of Vyshinsky A.Ya. de facto justified conviction of innocent persons, whose "guilt" was ascertained with illegally received "evidence" - anonymous examinations, "admissions" received against the will etc. [Vyshinsky, 1950]. CrPC RK provides several limitations of recognition of admissibility of 
evidence received with violation of CrPC provisions (deprivation or limitation of guaranteed rights of trial participants, or violation of other proceeding rules during investigation or trial), which influenced or could influence credibility of factual data. For example, following evidence shall be supressed:

- received though torture, duress, threatening, fraud or equally illegal actions;

- $\quad$ with the exploit of wrong belief of a trial participant as to his rights and obligations, arising from their nonclarification, partial or wrong clarification;

- $\quad$ in case if a procedural action was performed by a person not having a right to carry out proceedings as to a given criminal case;

- in case if a person subject to disqualification takes part in a procedural action;

- if procedure of procedural action was seriously infringed;

- $\quad$ from an unknown source or a source that cannot be identified at the hearing;

- $\quad$ with the use of averment methods contradicting to modern scientific knowledge.

With regard to the abovementioned, the CrPC stipulates that factual data received with infringements, mentioned in the first part of this article, can be used as evidence of act of infringing and of guilt of persons committed those infringements.

Inadmissibility of factual data as an evidence as well as possibility of its limited use under criminal proceeding shall be set by an agency conducting a trial, proprio motu or on request. Testimony of a suspect, an accused, a complainant and a witness, expert evidence, material evidence, investigation report, trial record and other documents cannot be the basis for persecution unless they are listed in the criminal case file. Evidence received through infringement are regarded as void and cannot be the basis for persecution or used to prove any fact indicated in Article 113 of CrPC RK. Particular emphasis should be put on the fact that both the Constitution (which is a directly applicable act) and new Criminal Procedure Code provide strict norms regulating evidence admissibility. Infringement of these norms invalidate the data received against the will or by illegal actions, so the data cannot be regarded as evidence.

In particular, there are provisions stating penalty of 3 to 8 years of imprisonment for compulsion the accused, complainant, witness of evidence or other illegal actions on the part of an investigator or an interrogating officer involving battery, abuse or torture. In this way our state as well as international society acknowledges importance and a need of effective measures for protection of the citizens' right. Such practice is also substantiated by exceptional nature of the situation, when because of high level of professional overwork and formal evaluation of results, confessionary statements stay the most efficient way to ascertain the person's implication in a crime. Meanwhile, prosecutors abuse their authority with no respect to the basic legal status of suspects and accused, who have a legal right to withhold evidence. This situation can in no way be described as exceptional, because a citizen is in the power of an official and is not capable to commit illegal actions. Criminal Procedure legislation presents many other legal ways to receive information about facts of a crime, crime committers, possible material and other evidences. Unfortunately, the use of abovementioned techniques depend on the level of professional knowledge of prosecutors, their intellectual superiority over the "adversary", ability to model criminal behaviour and create favourable psychological conditions for collaboration.

According to the part 4 Art.19 of CrPC RK, sentence of guilt may not be based on presumptions and it must be confirmed by sufficient aggregation of credible evidences. Here we again should refer to theory of averment. Credibility of evidence is a veracity of factual data received from sources prescribed by the law. Credibility of evidence is a result of thorough verification of data at the preliminary inquiry and in court. To provide credibility of data and possibility for verification, the law-maker establishes who, where and how can receive evidence to substantiate the facts. Evidence received by infringement of law are invalidated. The law establishes exhaustive list of sources to get information about circumstances which are relevant to the case.

At present the most discussed problem among the scientists and practitioners is an issue of necessity of evidence collection by court. According to part 1 Art. 366 CrPC RK, the court hearing studies evidences furnished by the parties. Chapter 44 of CRPC RK, regulating the trial, practically eliminate a possibility for the court to gather evidence of its own motion, except the right of court to commission an expert investigation. Though, this rule contradicts part 1 Art. 24 of CrPC RK, which states that the court, prosecutor, investigator, interrogating officer shall be obliged to take all measures provided for by law for comprehensive, full and objective examination of circumstances which are required and sufficient for correct settlement of the case. Having revealed components of a more serious crime in the actions of accused (or of crime essentially different from the one initially incriminated) the court shall not have the right - according to the Art. 340 of CrPC RK - to independently reclassify the accusations. Here a provision of part 3 Art. 19 of CrPC RK may be doubted, as it states that "any doubts which arise when applying criminal and criminal procedure laws must be settled for the benefit of the accused".

Article 323 of CrPC RK establishes following. According to the results of the preliminary hearing on the case, the 
judge without calling the main judicial proceeding shall direct the case for further investigation in the event of significant violations of the criminal procedure law are discovered, which impede the call of the main judicial proceeding. The same is applied to the main proceeding of cases of fast-track pre-trial procedure or of plea bargaining cases. Here the difficulty arises from an unsolved question as to which violations should be considered significant.

\section{Conclusion}

Criminal procedure law should be amended with provisions enabling court to remit the case for further investigation on its own initiative under circumstances provided by Art. 323 of CrPC RK, as well as giving the court a right for independent disclosure and examination of new evidence, the possible existence of which was discovered during the trial. As a rule, concealed nature of fabricated evidences or partiality of investigation is discovered just at the main trial and not at preliminary one. Complexity of circumstances, unpredicted behaviour of participants, facts revealed only during the main trial create such situation that to impel the judge to give sentence (condemnatory of absolutory) is to deprive him of a right to make an objective solution of case.

We suppose that settlement of these and similar problems in nearest future would promote filling of gaps in investigation, when an accused person is deprived of a basic principle of assumption of innocence - a full investigation.

\section{References}

Constitution of the Republic of Kazakhstan (adopted on August 30, 1995 at the republican referendum), Vedomosti Parlamenta Respubliki Kazahstan, 1996, №. 4, p. 217

Criminal Procedure Code of the Republic of Kazakhstan of June 4, 2014, No. 231 Kazahstanskaja pravda, 10.07.2014 No. 133 (27754);

Criminal Procedure Legislation of RK. General Part: Academic Course. Under the editorship of D.J.S. professor Toleubekova B.H. Part two. Almaty: HAS, 2004. 412 p.

International Covenant on Civil and Political Rights (New York, December 19, 1966). URL: http://adilet.zan.kz

Universal Declaration of Human Rights (Adopted by the resolution 217 A (III) of the United Nations General Assembly on 10 December, 1948). URL: http://adilet.zan.kz

Vyshinsky A.Ya. Theory of Judicial Proofs in Soviet Justice. Moscow, 1950. 308 p. 